Mikesell, Stephen L.

1988 Cotton on the Silk Road: Subjection of Labor to the Global Economy in the Shadow of Empire (Or the Dialectic of a Merchant Community in Nepal). Ph.D. Dissertation. University of Wisconsin, Madison.

\title{
THE PAST AND FUTURE OF SOCIOLOGY IN NEPAL
}

Bishnu Bhandari

Nepali, G. S.

The Newars. Bombay: United Asia Publications.

Rhoades, R. E.

1984 Breaking New Ground: Agricultural Anthropology. Peru: CIP.

Seddon, David, Piers Blaikie, and John Cameron

1979 Peasants and Workers in Nepal. New Delhi: Vikas Publishing House, Pvt. Ltd.

Seddon, David

1987 Nepal: A State of Poverty. New Delhi: Vikas Publishing House, Pvt. Ltd.

\section{Establishment of the Department}

The formal teaching of sociology in Nepal began with the inception of the Village Development Training Center (now called the Panchayat Training Center) in 1953. It was at that time that the Village Development Workers (VLW's) were given training about Nepali society and culture to help them to understand the dynamics of social change taking place in the society (Thapa 1974:45). The courses know by the name of rural society were confined to the training syllabus.

Because of the growing popularity of sociology in the universities abroad, its absence was felt in Nepal, especially after the episodes of social change brought out in the aftermath of the 1951 movement.

Consequently, the Vice Chancellor of Tribhuvan University expressed a desire for the immediate establishment of a department of sociology and anthropology in the university. As a result, Professor Ernest

Gellner, a short-term advisor from the London School of Economics, visited Nepal under the auspices of the British Council in September. 1970 in order to prepare a feasibility report on establishing a department of sociology in Tribhuvan University. Subsequently, a Department of Sociology/Anthropology was established at the Institute of Nepal and Asian Studies (INAS) (MacDonald 1974; Dahal 1984). The primary objectives of the Department as mentioned by Macdonald were mainly to:

1. carry out, encourage and, on occasion, supervise systematic social research in Nepal,

2. train Nepali scientists and researchers,

3. act as a clearing house and point of contact, coordination and cooperation for the various researches carried out in the past, present and future by Nepalis and foreigners [Macdonald 1974:27].

Gellner was appointed as a Professor of Sociology under a joint agreement between Tribhuvan University and the British Council. He

Occasional Papers in Sociology and Anthropology. Volume 2 (1990) 
also became the head of the Department of Sociological Research at INAS in 1973 for two years. His primary duties and responsibilities were as follows:

1. to train post graduate assistants and students,

2. to supervise and set their research projects.

3. to help them personally in the field, and

4. to assist them with the writing up of their material in view of publication in the form of Ph.D.'s or M.A.'s [MacDonald 1974:28].

Also, projects for the M.A. by dissertation. Ph.D. degrees and the examination were been drafted in collaboration with the dean of INAS to submit to the Faculty Board, which approved it immediately. As a result, three activities were done immediately in INAS. These included (1) the regular seminar on "The sociology of spirit-possession in Nepal" held on a weekly basis in the first semester of 1973, (2) recruitment of three researchers, Navin Rai for research on the Chepangs of Makwanpur and Chitwan districts, Drona P. Rajaure on the Tharus of Dang-Deukhuri and Surkhet Valley, and Dilli R. Dahal on the Athpahariya Rai of the Dhankuta District, and (3) admission of two Nepali students for M.A. degree, who were awarded degree-by-by dissertation by INAS.

Thus, in 1973, the cornerstone of the Department of Sociology was laid down and the basic infrastructure established by INAS However, the tradition of granting degrees by INAS did not last for long. There were changes of advisors, and the degree granting status of the institute was transformed into a the research center for conducting research. The name of INAS was changed to Research Center for Nepal and Asian Studies (CNAS), and the institute was deprived of granting degrees to students. The department of anthropology and sociology had to thus be kept alive by the people of CNAS.

It was not until several years later that moves were made to establish a new department. In 1977, five Nepali students were sent to India by Tribhuvan University on scholarships for masters degrees in Sociology and Anthropology. The following year, in 1978, the courses of study were prepared by the Institute of Humanities and Social Sciences. These moves paved the way for the Department of Sociology and Anthropology to be,opened under IHSS. The primary functions of the newly established department, as laid down in a department brochure were:

to provide a broad, interdisciplinary introduction to the twofields of Sociology and Anthropology, emphasizing the common

\section{THE PAST AND FUTURE OF SOCIOLOGY IN NEPAL}

theoretical roots and the disparate methodologies that characterize the two fields. ... makes every effort to relate its curriculum and field research to the needs of Nepal. The ultimate purpose is to provide students with the theoretical and practical tools that will enable them to assist in the development of the country as planners, administrators, social researchers and teachers [DAS n.d.].

Since its inception, the department has been offering courses only on the master's degree programs in sociology and anthropology. The students seeking admission in the department should have a bachelor's degree with a specialization preferably in one of the following subjects: sociology, anthropology, economics, political science, history, geography, psychology, home science or culture (Bhattachan 1987).

The first M.A. degree in sociology and anthropology was granted by the department in the year 1985. As of 1989, six batches of students had already graduated from the department.

The teaching of sociology is not confined to the masters level only. Other campuses offer sociology courses at the undergraduate level. These are the Patan Multiple Campus at Lalitpur. Tri-Chandra Campus at Kathmandu, P. N. Campus at Pokhara, and Mahendra Morang Campus at Biratnagar. The ten other campuses which have been authorized to offer courses on sociology and anthropology at the undergraduate level include (1) Padma Kanya Campus, (2) Bhaktapur Multiple Campus, (3) Thakur Ram Multiple Campus, Birganj, (4) Dharan, (5) Janakpur, (6) Palpa, (7) Bhairawa. (8) Dang, (9) Nepalgunj, and (10) Bajhang.

Besides instruction in sociology at the faculties of humanities and social sciences, some courses are taught in professional and technical institutes too. For example, some courses on medical sociology are being offered at the Institute of Medicine, and a few courses on rural sociology and urban settlement are being taught respectively at the Institutes of Forestry and Engineering. The Institute of Agriculture and Animal Science has indeed established a full-fledged department of Agricultural Extension and Rural Sociology in Rampur, and it offers about eight courses on rural sociology and th sociology of economic change, including a course on survey research methods at the bachelor level in agriculture. A course on the sociology of education is taught at the faculty of Education in Kirtipur.

The department in Kirtipur has also made some arrangements to provide Ph.D. degrees to qualified and competent researchers selected by the university. The department grants Ph.D. degree by dissertation to students. At the moment, there are three students enrolled in the Ph.D. program under the guidance and supervision of the department's faculty members. 


\section{Courses of Study}

Some fourteen faculty members are currently engaged in teaching in the department. The outline of the course of study offered by the department for its M.A. students is as follows:

\section{First Year Courses}

Paper 1. Foundation of Sociology/Anthropology

Paper 2. Theory in Sociology Second Year Courses

Paper 3. Theory in Anthropology Paper 7 Specialization Course

Paper 4. Methodology of Social Paper 8. Dissertation Writing Research

Each year the department offers two out of the eight courses in each area of sociology and anthropology. The decision over the topic of the specialization courses depends upon the availability of teaching manpower and the number of students enrolled in the course.

\section{Research Affiliation}

Over the course of nine years the department has attracted over 1,000 students into its masters degree program. As mentioned above, three students have already joined the Ph.D. program. The department also has some foreign students from the United States, Bangladesh, India and Shri Lanka.

In addition to its regular teaching program, the department has established research affiliation with more than seven universities in the United States (Wisconsin, Cornell, Chicago, Michigan, Colorado, Seattle and Minnesota), the University of London in England, the University of Zurich in Switzerland, the Universities of Bergen and Oslo in Norway, the University of Helsinki in Finland, and the University of Tokyo in Japan. Graduate Students come from these universities to research Nepali society and culture. Also, bachelor level students come every year from the University of WisconsinMadison to stay for one year as part of Wisconsin's College Year Program in Nepal, which is also affiliated with the Central Department of Sociology and Anthropology in Tribhu'van University.

Many Nepali scholars in the field of sociology and anthropology go abroad to pursue higher studies under the auspices of programs such as the Wenner-Gren Foundation, WINROCK International, F/FRED, Ford Foundation, East-West Center, America-Nepal Education Foundation. The United States Education Foundation, etc.
As mentioned elsewhere, sociology is a nascent subject in Nepal. However, its significance has been gradually realized in research and academia. Because of its youthfulness, it has confronted a tremendous number of problems in becoming an established discipline. some of which are elaborated below.

\section{Inadequacy of Trained Locals}

As mentioned above, the discipline is in its infancy and in the process of developing inwardly as well as outwardly. Because of this, it has established few career opportunities yet. Salaries are unattractive and and working conditions discouraging. The majority of sociologists are employed by the university, where they share heavy teaching loads hampered by the unavailability of texts and reference books. All these reasons make for a brain drain to foreign and private agencies, to consultant services within Nepal, or to jobs abroad.

\section{Lack of Text Books}

Generally, books are either in English or Hindi, with a dearth of Nepali books dealing with Nepali problems. This problem of unavailability has been further aggravated by instruction in English and the citation of foreign examples to the exclusion of Nepali ones.

\section{Lack of Funds}

There are insufficient funds to conduct either basic or applied research. Unless funds are made available, new knowledge and information cannot be generated for use in teaching and research. The shortage of funds prevents sociologists from traveling to different parts of the country for independent research. There is a crisis in the generation of knowledge, and the priorities for knowledge are set by well-funded foreign researchers.

\section{Lack of a Theoretical Framework}

A great deal of studies have been done on Nepali society and culture by both foreigners as well as local scholars. These studies are of a descriptive nature and apply simple statistical techniques. The general feeling is that they have neglected history and concentrated only on the present, using simple causation to explain problems.

\section{Lack of Commitment}

Commitment to the discipline is lacking, resulting in a failure to make the discipline into one with a specifically Nepali character. The professional sociologists - few in number as they are - are most of the time engaged in consultancy, private projects, etc., funded by foreign or private agencies. Research projects conducted by researchers paid 
by others set agendas irrelevant to the national discourse. They art of low academic quality, and certainly not of an international standard Also, due to this problem of commitment to the intellectual development of the discipline, neither can the best students be attracted nor the qualified professionals be found working in the discipline. Those who wish to pursue their careers in sociology need to be supported by scholarships, research grants, and grants to attend local and international seminars. Funding agencies must be tapped and priorities of research should be fixed.

\section{Lack of Professionalism}

Along with the problems mentioned above, there is a lack of association to facilitate interaction and communication among trained professionals. There are few forums to share experiences, knowledge, and information. The only association, the Sociological

Anthropological Society of Nepal (SASON), is inactive. There is no systematic attempt to publish material. Emphasis should be given to organize seminars, symposiums, conferences, etc. The professionalism should be developed so as to develop a wellestablished linkage with other professionals in the region as reference groups. There is also little activity outside the country. which has kept our profession academically isolated. Great changes must be made to develop an independent and autonomous full-fledged profession.

\section{Agenda for the Future}

The agenda of sociology is of great breadth. However, the means to attack the different problems are limited. Thus, some sort of priority must be given. The following are suggestions in this vein.

\section{Enhance Awareness About Sociology}

Sociology is a nascent subject in Nepal. It is in a stage of great innovation. A majority of people do not know about sociology or what role it has in society. Thus, people need to be made aware through the publication of scholarly and popular books and articles, public speaking. and brochures.

\section{Create More Career Opportunities for Graduates}

Places of employment should be explored by the department so as to attract serious and talented students. University careers alone are insufficient and undesirable to absorb the growing number of graduates.

\section{Define Research Areas to be Covered}

Potential areas of research by the discipline should be identified in order to better utilize limited resources, funds, and manpower. In light of the current situation in Nepal, potential areas may include poverty, regional inequality, class formation, agrarian class, people's participation, social problems, basic needs, decentralization, women's studies, land tenure systems, population, environment, prescriptive research, the state, etc.

\section{Adopt Inter-disciplinary Approaches to Study Problems}

Use the nascent condition of sociology to our advantage by redefining it to suit Nepal's domestic and international situation.

\section{Revive SASON}

As mentioned above, SASON seems to be in a state of dormancy and needs to be reawakened to develop the contacts and sharing of information. experience and knowledge between members of the profession.

\section{Publish a Regular Professional Jouma}

A forum is needed to systematically share research findings and ideas. At least a bulletin, but preferably a journal or both needs to be published.

\section{Utilize More Types of Data and Information Sources}

At the present, researchers tend to limit themselves to survey, library, and census data.

\section{Establish a National Institute for Social Science Research}

There is a need for an autonomous, non-profit national research institute to sponsor scholarly activities and coordinate activities.

\section{Shift the Focus of Research from the Descriptive to the Prescriptive}

The large body of knowledge that has resulted from "exploration and description" of the Nepal situation is insufficient to make the discipline a complete science. There is a need for explanation and a shift from asking "what" and "how" to "why" and "what must be done."

\section{Strike a Balance between the Quantitative and Qualitative}

Qualitative as well as quantitative information are the two sides of complete research work. Research in Nepal tends to be heavily 
biased in one aspect or another. Studies that overemphasize the quantitative can be interpreted in many different ways and consequently used to justify almost anything. An overemphasis on quality often is not taken seriously. Work should be balanced between the two, and grounded simultaneously in rigorous empirical data and theory.

\section{Move Towards Institutionalization}

A forum should be provided to provide greater opportunity for inter-disciplinary and inter-sectorial interaction between

professionals. Periodic seminars, refresher courses, and conferences should be organized to upgrade the discipline. Various kinds of support such as scholarships, research and publication grants, travel grants etc. are necessary.

\section{Making the Discipline Indigenous}

While an identity is important for advancement of an autonomous discipline and its interests, departmental compartmentalization and professional chauvinism hinder the "inter-disciplinary as well as multidisciplinary" efforts and autonomy. Borrowed modes of theory often adulterate the society and culture and prevent understanding our own society and its problems. Sociology has a national character in other countries, so why not here? (Bista 1980, 1987a and 1987b).

There is a need to develop methods and techniques suited to local conditions. To achieve this, teaching and research problems must be reoriented. Nepali examples should be given in the classroom. The medium of instruction should be in Nepali, and educational materials need to be made available.

\section{Determine Ideological Courses of Action}

The future course of action should be defined by the discipline so as to identify the areas of research. Target groups, areas, etc. must be identified. Research should be practically oriented. The level and standard of research needs to be maintained, and accompanied by the development of an academic culture encouraging professional ethics and honesty.

\section{Appendix: Chronology of the Department}

1953 Rural sociology is taught in the Village Development Training Center for low level manpower

1970 The Vice Chancellor of Tribhuvan University expresses concern about the absence of a sociology department.

1970 Professor Emest Gellner visits Nepal to prepare a report on establishing the Department of Sociology/Anthropology

1973 Establishment of the Department of Sociology/Anthropology in the Institute of Nepal and Asian Studies

1977 Five students are sent to India by Tribhuvan University to obtain M.A. degrees in Sociology and Anthropology

1978 The dean forms a committee, IHSS, to explore the possibility of opening a Department of Sociology/Anthropology

1979 Formation of a curriculum Draft Action Committee to prepare a course of study for an M.A. program

1981 Establishment of the Department of Sociology/Anthropology

1984 Formation of the Sociological Anthropological Society of Nepal (SASON) Ad Hoc Committee

1985 Undergraduate level sociology and anthropology courses begin at four campuses

1985 Registration of SASON with HMG

1985 Election of the First Executive Committee of SASON with Professor Dor Bahadur Bista as its first president

1985 First M.A. Degree granted by the department

1986 Department of Anthropology/Sociology renamed Central Department of Anthropology and Sociology

1986 Publication of the first issue of the SASON Newsletter

1987 One day seminar on "Sociology/Anthropology and Development" held to mark the first anniversary of the department

1987 Publication of volume 1 of Occasional Papers in Sociology and Anthropology by the department 


\section{References}

Bhattachan, Krishna Bahadur

1978 Sociology and Anthropology Curriculum and the Needs of Nepal. Occasional Papers in Sociology and Anthropology. James Fisher, ed. 1:11-28

Bista, Dor Bahadur

1980 Prospects for Anthropology in Nepal. A Paper submitted to the Social Science Seminar. Tribhuvan University Kirtipur.

1987 Nepal School of Sociology/Anthropology. Presidential Address at the Seminar on "Sociology/Anthropology and Development" organized by SASON, May 6 .

Bista, Dor Bahadur, T. S. Thapa and D. R. Dahal

1978 Research in Anthropology/Sociology [In Nepali]. Tribhuvan University Journal. Special Issue: Research in Tribhuvan University: Problems and Prospects, 10(1)

Dahal, D. R.

1984a Anthropology in Nepal: Infrastructure and Development In Social Science in Nepal: Infrastructure and Program Development, pp. 37-57. Kirtipur: Institute of Humanities and Social Sciences (IHSS), Tribhuvan University.

1984b Himalayan Anthropology: A Review. Preparatory Workshop on Himalayan Studies, Ananda Shrestha, ed. Kirtipur: Center for Nepal and Asian Studies, Tribhuvan University.

Department of Anthropology and Sociology (DAS)

n.d. An Introduction to the Sociology and Anthropology Department. Kirtipur: Tribhuvan University.

Macdonald, A. W.

1974 Sociology and Anthropology in Nepal. Social Science in Nepal, Padma Ratna Sharma, ed. Kirtipur: INAS. Tribhuvan University.

Mishra, Chaitanya

1980 Socialogy in Nepal: Challenges for the 1980s. A paper presented to the Social Science Seminar. Tribhuvan University - Kirtipur.

1984 Social Research in Nepal: A Critique and Proposal. Contributions to Nepalese Studies, 11(2).
Ojha, Y. N., S. P. Adhikary, Y. S. Thapa and R. R. Misra

1987 Application of Anthropology and Sociology in Civil

Service. A paper presented at the Seminar on

"Sociology/Anthropology and Development," organized by SASON, May 6.

Rai, Navin $\mathrm{K}$

1974 Critique on Sociology and Anthropology in Nepal. In Social Science in Nepal, P. R. Sharma, ed. Kirtipur: INAS, Tribhuvan University.

\section{SASON}

1986 SASON Newsletter 1(1).

Thapa, T. S.

1974 The Development of Sociology in Nepal. In Social Science in Nepal, P. R. Sharma. Kirtipur: INAS,

Tribhuvan University.

UNESCO

1985 Sociology and Social Anthropology in Asia and the Pacific. New Delhi: India Wile Eastern Limited.

Upreti, T. N.

1983 Western Scholars' Contributions to Nepal Studies. An

after-luncheon talk delivered at the 11th Annual Conference on South Asia. Madison: University of Wisconsin - Madison. 